\title{
1. The role of the Regional Innovation System approach in contemporary regional policy: is it still relevant in a globalised world?
}

\author{
Bjørn T. Asheim, Arne Isaksen and \\ Michaela Trippl
}

\section{INTRODUCTION}

Schot and Steinmueller (2018) argue that science, technology and innovation policies can be framed in three different ways following the Second World War. The first framing, which they call 'R\&D' (research and development), lasted until the 1970s; the second framing, referred to as 'National Systems of Innovation', peaked around 2010, but is still very influential; and the third framing, 'transformative change', has been increasing in importance since 2010, with its focus on how to solve grand societal challenges (Schot and Steinmueller, 2018). The Regional Innovation System (RIS) approach is an outcome of the second framing, and came into dominance in the 1990s (Asheim et al., 2019).

In this chapter we ask whether the RIS approach is still relevant in a globalised world that is increasingly confronted with grand global and societal challenges such as climate change, lack of economic growth, and high levels of social and regional inequality, as well as an ageing population, problems that either were not recognised in the 1980s and 1990s, when the innovation system approach was developed, or were not present during those decades. We also ask, how can the RIS approach still be relevant, and which changes in the approach would have to be implemented, for it to continue to be a powerful tool for designing and implementing regional (innovation) policies directed towards promoting transformative changes?

We seek to answer these questions via several steps. Firstly, we give a short account of how regional (innovation) policy has been transformed during the period of the three framings. In a next step we present in further detail the development of 'RIS-based policy' during the second framing. 
We then propose some important changes the RIS approach must undergo to continue to be a relevant tool in the age of transformative change. We use examples from regional (innovation) policy in Europe to illustrate our discussion, and we end with reflections on RIS dynamics and our conclusions.

\section{REGIONAL POLICY IN THE THREE FRAMINGS}

\subsection{The First Framing - 'R\&D'}

In the aftermath of the Second World War, there was a strong focus on rebuilding Europe after the massive destruction that took place during the war years. Abundant economic resources were mobilised, e.g. through the Marshall Plan, to restart the engines of society so as to promote economic growth and increase standards of living as quickly as possible. One instrument of this strategy was allocating resources to R\&D as an important way of boosting economic growth. This strategy is an example of the linear model of innovation, in which investments in R\&D comprise the key variable in achieving increased competitiveness of firms and nations through new and improved products and processes. This view was launched by the American scientist Vannevar Bush (1945) in a report entitled Science: The Endless Frontier. The report expressed a strong belief in the potential economic impact of investments in science (Lundvall and Borrás, 2005). It was the first time science policy became a policy area. Science was looked upon as a productive force that could be economically and socially useful.

This linear view of innovation was a supply-based strategy, in which R\&D input into the production system was the most important factor. Thus, the focus was on building the exploration capacity of firms and regions/nations, and no serious considerations were devoted to the diffusion and adoption dimensions of new technologies, nor to the strengthening of the exploitation capacity of firms. It was taken for granted that available new technologies would be automatically diffused and adopted by firms. ${ }^{1}$

In regional policy, this first framing of R\&D was only partly manifested in the so-called 'Growth Centre' strategy. This strategy built on work by the French regional economist Perroux (1970) on 'Growth Poles', developing perspectives on concrete geographic and abstract economic space. The background for Perroux's development of his theory was the provision of a theoretical framework for the establishment of the European Coal and Steel Community in 1951, which was a forerunner and model for the formation of the European Economic Community (EEC) in 1957. 
Perroux argued that companies exploiting agglomerated external economies, i.e. localisation economies, in concrete geographic space, could intensify the benefits of external economies. Growth Poles in concrete geographic spaces were constituted by firms belonging to the same or closely supporting sectors (e.g. as a result of sector specialisation). Perroux asserted that firms within a Growth Pole were more innovative than firms outside a Growth Pole due to the impact of the 'key' or 'motor' industry of the Growth Pole, which is defined as an over-average innovative firm and which made the whole Growth Pole more innovative by impacting the other firms in the Growth Pole through knowledge spillovers and inputoutput linkages. This perspective on industrial and innovation policy was later revitalised by Porter's cluster concept in the 1990s. ${ }^{2}$

In the 1960s this was developed into a generalised regional innovation policy approach of Growth Centres, which became an important policy instrument in Europe for a couple of decades, aiming at generating regional multiplier effects that would promote economic growth in the regions (Holland, 1976). In addition to developing Perroux's Growth Pole theory, the Growth Centre approach was informed by Myrdal's (1957) and Hirschman's (1958) perspectives on unbalanced growth. The idea was that Growth Centres should promote spread or trickle-down effects from the centre to the surrounding peripheral regions, but often the result was that the backwash or polarisation effects were stronger, increasing regional inequalities between centre and periphery.

\subsection{The Second Framing - 'National Systems of Innovation'}

Following the oil shocks of the 1970s and the serious recession at the beginning of the 1980s, it became obvious that the linear model of innovation of the 'R\&D' framing was not sufficient to generate the necessary level of economic growth. The economic crisis also intensified the competition between countries, which highlighted the differences in countries' innovative and productive performance. In this context it is important to note that the concept of innovation systems was introduced focusing on economic competitiveness. The aim of the Organisation for Economic Co-operation and Development (OECD) expert group in the 1980s, which developed the concept, was to provide a dynamic approach to international competitiveness as an alternative to the static, cost-based view of international trade theory on how to promote competitiveness. Basing their insights on the principle of comparative advantage, protagonists of this traditional view argued that international competitiveness was achieved by having the most cost-efficient production of products and services. The OECD expert group presented a different view, arguing that international competitiveness 
could be achieved through promoting learning and innovation in societies, i.e. that competition was based on a country's innovativeness (Freeman, 2004). This idea was used ten years later by Porter, who argued for the role of clusters driving innovation, resulting in firms and countries obtaining competitive advantage (Porter, 1990).

Also in other dimensions, the innovation systems approach represents important theoretical and policy advances. Placing innovation at the centre of economic growth, it introduces innovation for the first time as interactive learning processes that take part between multiple actors and organisations (entrepreneurs, firms, universities, public agencies, government and civil society). This stands in contrast to the hitherto-dominating supply-side, linear model of innovation, in which innovation was seen as the outcome of a unidirectional process from basic via applied R\&D to new products and processes. Innovation systems, thus, constitute the first explicit innovation policy approach compared with the previously dominating science and technology policies (Lundvall and Borrás, 2005). This is also the first policy approach emphasising that long-term relationships between key stakeholders (university, industry and government/ public sector) can play a strategic role in the promotion of innovation and competitiveness, implying that not only the exploration capacity of the national system (i.e. the research infrastructure) was emphasised, but so too was the exploitation capacity of firms. Key to this focus on the exploitation side was the absorptive capacity of firms, which pointed to the educational level of people and firms. To generate employment growth and economic development, new technologies must be considered useful and relevant for industry, which to a high degree depends on the firms' absorptive capacity.

The National Systems of Innovation approach was directly influencing the development of the RIS approach at the beginning of the 1990s (Cooke, 1992; Asheim and Isaksen, 1997). The approach was also informed by the endogenous development that took place in the industrial districts of the Third Italy (the Central and North-Eastern regions of Italy), which was described as a transition from Fordism to Post-Fordism representing a second industrial divide in the history of capitalist industrialisation (Piore and Sabel, 1984). Post-Fordism rests on flexible specialisation as the basic organising principle of industrial production, i.e. semi-customised batch production carried out by a geographically agglomerated network of small and medium-sized enterprises (SMEs). The linear model was instrumental to the Fordist industrial model of large companies, often with their own R\&D department, manufacturing standardised mass products.

In the context of the European Union (EU)'s regional policy agenda, the RIS perspective firstly became manifested in policy initiatives promoting 
technology transfer between university and industry in programmes and initiatives such as the European Commission's Regional Technology Plan (RTP) and further in DG XVII's Regional Innovation \& Technology Transfer Strategy scheme and in DG XIII's Regional Information Society Initiative. The outcome of these initiatives, however, was a tendency to favour a one-size-fits-all approach (Tödtling and Trippl, 2005), where all regions opted for the same high-technology clusters, reinforcing the advantage of core regions. The exception in this picture was the Regional Innovation Strategy pilot actions launched by DG XVI, which were part of new policy developments in Europe in the 1990s to promote economic development through innovation in less developed regions within the EU (Bellini and Landabaso, 2007). In this action the concept of Learning Regions was applied as a strategy to develop more complete regional innovation systems, which owes much to the national innovation systems approach, in which capabilities of learning play a central role (Asheim, 2012).

However, the need for a more place-based, differentiated regional innovation policy that appreciated the huge differences within the heterogeneous landscape of regions in Europe, became increasingly more obvious, and in 2004, DG Research established an Expert Group for the purpose of developing a strategy called 'Constructing Regional Advantage' (Asheim et al., 2006; Asheim et al., 2011). The main message of the Constructing Regional Advantage (CRA) approach was to promote competitive advantage through an innovation-based differentiation strategy creating unique products and services, building on the view that this can be achieved in all types of industries and regions, yet based on the industry-specific modes of innovation and knowledge bases.

Thus, the CRA approach represented a broad-based innovation policy. This makes the approach instrumental in designing and implementing an innovation-based policy for promoting diversified specialisation. Moreover, as the aim of the CRA approach was to inform the development of regional innovation strategies, it constituted an explicit spatial, placebased approach.

The CRA approach implies that competitive advantage has to be constructed on the basis of the uniqueness of firms' and regions' capabilities (Asheim et al., 2006). As an important initial strategy for new path development, regions and countries should base their competitive strategy on industries in which they have traditionally been doing well. In designing and implementing the CRA strategy, RIS played a key role.

The CRA approach was followed by Smart Specialisation Strategy (S3), which was launched by the EU as a strategic approach to an innovation-based policy for regional economic development. It is the basis 
for European Structural and Investment Fund interventions in research and innovation (R\&I) as part of the future Regional and Cohesion Policy's ambition for the European 2020 job and growth agenda to achieve a smart, inclusive and sustainable economy. The presence of an S3 strategy is a requirement as part of the next conditionality framework for a member state wishing to use its European Regional Development Fund (ERDF) for innovation activities. This is why all member regions in the EU have had to design and implement this strategy to receive structural funds in the coming years towards 2020 .

S3 is probably the single largest attempt ever of an orchestrated, supranational innovation strategy to boost economic growth through economic diversification and new path development, e.g. diversifying the economy into technologically more advanced activities that move up the ladder of higher knowledge complexity and value creation compared with the present level in the region (Asheim et al., 2017). The aim is to plan for economic diversification in the short- and medium term, in addition to establishing a long-term perspective for promoting more fundamental structural changes in the economy through transformative activities. S3 represents an explicit, place-based approach, emphasising prioritisation through non-neutral, vertical policies as well as, for the first time in the EU's history, providing a policy framework for promoting and implementing a broad-based innovation policy. Thus, it could be argued that $\mathrm{S} 3$ in many ways builds on insights from the CRA approach (Asheim et al., 2011; Boschma, 2014).

$\mathrm{S} 3$ is not about 'specialisation' as known from previous regional development strategies, i.e. a Porter-like cluster strategy, but about diversified specialisation. What this means is that regions (and countries) should identify strategic sectors - or 'domains' - of existing and/or potential competitive advantage, in which they can specialise and create capabilities in a different way from other countries and regions. They should diversify their economies primarily based on existing strengths and capabilities by moving into related and unrelated sectors. S3 should build on 'each region's strengths, competitive advantage and potential for excellence' and 'support technological as well as practice-based innovation' (European Commission, 2014, p. 2).

'Smart' in the S3 approach refers to the identification of these domains of competitive advantage through what is called the 'entrepreneurial discovery' process. However, the emphasis here is not on the role of traditional entrepreneurs, resulting in a policy focus only on firm formation and start-ups as an individual entrepreneurial project. As underlined in the writings on S3, 'entrepreneurial' should be understood broadly to encompass all actors with an entrepreneurial mindset, including innovative 
(Schumpeterian) entrepreneurs at the firm and company level, institutional entrepreneurs at universities and in the public sector, and place leadership at the regional level with the capacity to discover domains for securing existing and future competitiveness (Grillitsch and Sotarauta, 2018). Such a broad interpretation of 'entrepreneurial discovery' as a public-private initiative avoids the pitfall of ignoring the systemic nature of innovation as interactive learning involving a number of stakeholders. The systems approach to innovation policies also highlights the role of the public sector in driving innovation, as well as the balance between exploration and exploitation (Asheim and Gertler, 2005; Asheim et al., 2016).

The RIS approach can basically be viewed as an innovation-based theory of competitive advantage, i.e. representing a 'high road strategy' for regional economic development that consists of a process of economic diversification (structural change) in addition to mere economic growth (expansion). Furthermore, it also represents a focusing device for designing this strategy, as it points to the necessary (but not sufficient) components to put in place for implementing such a policy. It has, thus, also been shown to be instrumental for the design and implementation of S3 strategies.

Consequently, the RIS approach can be used for analysing why regions experience positive or, alternatively, less favourable economic development as well as for assessing how well policies for regional economic development have been designed and implemented (Trippl et al., 2019). During the years since the concept's introduction, the approach has mostly been viewed as an instrument for policy analysis, while the original use of the approach to promote innovation, economic growth and competitiveness has been rather ignored or forgotten, especially in academic research, even if it has been used to explain the uneven geography of innovation and economic development (Asheim and Gertler, 2005; Asheim et al., 2016).

However, in policy contexts, e.g. represented by Swedish government agency VINNOVA's regionally focused innovation policy, the growth and competitiveness perspectives have clearly been present. VINNOVA aims to create strong research and innovation milieus with a regional focus but with national and international linkages, which should strengthen Sweden's international competitiveness.

Regional innovation systems have played and will continue to play a strategic role in promoting the innovativeness and competitiveness of regions, which is the overall mission of innovation policy in the second framing. The RIS approach has lately been strengthened by attention being directed towards the need perceived by policy makers at both EU and regional levels to construct regional advantages (Asheim et al., 2006), recently within the framework of its S3 policy as described above. Thus, the RIS approach is still an efficient instrument for the design and implementation 
of the S3 strategy. It combines horizontal policies (e.g. promoting university-industry collaboration and building capacities in KETs [key enabling technologies]) and vertical place-based, direct and specific policies (e.g. VINNOVA's 'strong' R\&I milieus). Moreover, policies inspired by the RIS approach represent a combination of top-down (horizontal) and bottomup (vertical) approaches, in which the bottom-up part also constitutes an entrepreneurial discovery process involving regional stakeholders.

However, what about the potentials of the RIS approach to meet the requirements of the third framing of innovation policy, i.e. transformative change? Under this approach, the rationale for policy intervention is less to fend off market failure and to correct system failures than to shape and create markets (e.g. through the use of innovative public procurement) to address grand societal challenges and to solve capability constraints and reduce deficits within regional innovation systems with regard to interaction, connectivity and direction (Tödtling and Trippl, 2018; Asheim et al., 2019).

\subsection{The Third Framing - 'Transformative Change'}

A starting point for this discussion is the EU's ambition to become a smart, sustainable and inclusive economy by 2020 , which is the overall aim of the Horizon 2020 funding programme. As Smart Specialisation Strategy (S3) is part of Horizon 2020, this is also the overall aim of S3. The 'inclusive' dimension relates strongly to key parts of the cohesion policy. Here, the aspects of promoting an economically and socially sustainable society take priority by integrating all citizens and regions in benefits resulting from economic growth and prosperity. In a Europe still suffering from too high unemployment, especially of young people particularly in Southern and Eastern Europe, this is a huge challenge. Consequently, an economic and innovation policy within the EU has to be 'smart' also in the sense that it can provide good, stable and well-paid jobs to all its citizens in all its regions.

S3 policies have a greater potential of achieving this than previous linear innovation policies due to the application of a broad-based approach to innovation and to the practice of taking the existing strengths and competitive advantage of regions as a starting point for the design of S3 priorities. This makes it possible to prioritise sectors with different modes of innovation and knowledge bases, and not only to try to boost high-tech sectors, which would only benefit already well-developed regions and only provide high-skill jobs. This would not serve well the majority of regions in the EU, especially in Southern and Eastern Europe, and it would lead to reduced cohesion socially and regionally; thus, it would be neither 
'sustainable' nor 'inclusive'. A broad-based approach to S3 could develop a wide number of sectors that provide a majority of jobs in many Southern and Eastern European regions, and, thus, it is vital to the regional economy (e.g. tourism as a classical example) and would represent an 'inclusive' development.

An S3 priority focusing on the tourism sector should then strengthen the sector's competitive advantage by identifying unique regional assets that would differentiate it from the tourism sector of other competing regions, and enable it to climb the value-added ladder. Applying a 'sustainability' dimension in such a strategy would be logical.

Moreover, the success of achieving this depends to no small extent on the way the entrepreneurial discovery process is practised, or, more precisely, how collective this process is. If a narrow interpretation is used, with only entrepreneurs from the business sector being involved, the outcome would probably in the best cases be only 'smart', meaning profitable for the entrepreneur him-/herself but not qualifying as either 'sustainable' or 'inclusive'. A broader involvement of other stakeholders would probably make it easier to achieve, and to use the entrepreneurial discovery process to contribute to solving grand societal challenges as part of a region's S3 strategies.

Many of these societal challenges are related to the health and welfare sector, e.g. ageing and generally increasing public costs of providing sufficient public health services. In welfare states, the public sector is responsible for providing most of these services, and, thus, it represents a large and critical customer. This gives the public sector a strong motivation to drive innovation and entrepreneurial discovery processes as part of a public procurement of innovation (PPI) policy. This sector should also to an increasing degree involve users in developing innovations to improve the lives of patients with chronic diseases. Such user-driven innovations, involving 'ordinary' citizens (i.e. civil society actors), are a very good example of social innovations, including non-profit-seeking actors in the entrepreneurial discovery process. Academia can also play a key role in initiating and accommodating such user-driven innovations, as the 'Patient Innovation Lab' at the business school of the Catholic University in Lisbon illustrates (Oliveira et al., 2015).

To achieve a sustainable and inclusive social and economic development requires a long-term perspective, which is more easily realised with a strong commitment from the public sector. In an EU context this is pursued through a focus on solving grand social challenges such as energy supply, public health, ageing and climate change. In several regions, one or more of these challenges is part of the $\mathrm{S} 3$ (Trippl et al., 2019). The policy instrument to achieve this is 'system innovation policy', which the OECD 
defines as 'a horizontal policy approach that mobilises technology, market mechanisms, regulations and social innovations to solve complex societal problems in a set of interacting or interdependent components that form a whole socio-technical system' $(2015$, p. 7$)$.

This represents a reorientation of the strategic focus from a place-based to a 'societal change-driven' policy transcending sectoral, geographical and organisational domains, which reflects a recent trend in European innovation policy. The aim of system innovation policy is to secure international competitiveness within thematically coherent but technologically and cognitively diverse areas to promote economic growth and provide solutions for grand societal challenges.

A broad-based innovation policy is better aligned to support a system innovation policy; as such a policy points to the need for reaching a balance between demand-oriented and supply-led strategies, in which place-specific context matters and innovation policy can be attuned to and embedded in the particularities of the regional and national economies it claims to target. However, a shortcoming of a system innovation policy approach is precisely the lack of such place-specific focus. Linking S3 with system innovation policy could, thus, be a solution to achieving a smart, sustainable and inclusive economy in the EU by 2020 (Asheim and Moodysson, 2017).

So, what modifications, adaptations and changes must be undertaken to make the RIS approach able to accommodate the needs for broader stakeholder involvement, stronger presence of agency and an expanding role of the public sector to strengthen the demand side of innovation policies, in addition to a continued upgrading of the importance of non-regional resources, knowledge linkages, and production and innovation networks?

In concrete terms, a broader stakeholder involvement can be achieved by expanding the RIS framework from a triple-helix to a quadruple-helix constellation by including civil society and non-governmental actors and agencies. This is already the ambition of S3 in the promotion of social innovations. An increased role of agency has also been pursued in $\mathrm{S} 3$ by the central position of the entrepreneurial discovery process in the implementation of the strategies, especially when using a broad and inclusive understanding of what is an entrepreneur. In the RIS approach this could be accommodated by explicitly allowing for different types of entrepreneurship in the 'boxes' of industry, university, public sector and civil society. And, lastly, the extended role of the public sector not only to correct market and system failures but also to shape and create markets to develop a critical demand for new products and services that can contribute to solving the grand societal challenges is a key factor in the new push for mission-oriented innovation policies (Mazzucato, 2017), which is high 
on the innovation agenda of the EU and many countries both in developed and emerging economies.

In general, these changes must lead to the RIS approach becoming more dynamic, opening up for continuous experimentation and learning as well as the formation of new bridging networks that link up previously unconnected actor groups and agencies to form coalitions better positioned to solve grand societal challenges (Tödtling and Trippl, 2018; Asheim et al., 2019). This points towards the urgency of coming up with new institutional practices and governance structures that transcend the existing segmented divisions between government, markets and civil society.

\section{RIS DYNAMICS AND REGIONAL STRUCTURAL CHANGE}

In this section, we seek to explain how the RIS approach could lead to a better understanding of how regions (need to) reconfigure their organisational and institutional support structures for facilitating regional structural change and dealing with grand societal challenges. This is a key issue as the literature maintains that well-coordinated and stable regional innovation systems often support the further strengthening of dominating regional industries and established practices (Boschma et al., 2017; Weber and Truffer, 2017). Basically, then, RISs sustain regional industrial path extension and to some extent path upgrading rather than new path development, although the ability to initiate new paths differs between types of RISs due to varying degrees of regional organisational and institutional thickness and different capacities to absorb and anchor extra-regional assets (Isaksen and Trippl, 2016; Zukauskaite et al., 2017; Trippl et al., 2018). The 'lock-in approach' (Grabher, 1993) contributes to explaining the fact that RISs tend to support continuity rather than transformation. Lock-in stems from close networks between regional firms and between the political-administrative system and the regional industry. Strong regional industries also become institutionalised over time, in the sense of being embedded in the wider regional economy and society.

Based on these arguments, regional structural change may require that RISs change so that they are better equipped to support the emergence of new regional industries and innovations that contribute to solving grand societal challenges. The transformation of RISs can be of three main types (Tödtling and Trippl, 2013). Firstly, RIS transformation may involve the establishment of new organisations (such as an incubator or a prototype lab) or changes within existing organisations (such as new study programmes offered by existing educational bodies) (Miörner and Trippl, 
2017). Secondly, RIS is transformed through new or changed relations between organisations, such as increased interactive learning between firms and between firms and universities (as a result of, for example, cluster policy programmes) or collaborative practices involving a larger variety of players belonging to complex quadruple-helix actor constellations. Thirdly, RIS transformation can include changes in laws and regulations and in informal institutions, such as the emergence of new routines and patterns of behaviour (Tödtling and Trippl, 2013).

Such RIS changes do not, however, occur automatically but call for agency in the meaning of an 'action or intervention by an actor to produce a particular effect' (Sotarauta and Suvinen, 2018, p.90, drawing on Emirbayer and Mische, 1998). This leads to the understanding that transformative changes must be supported by agency that develops and adapts RISs to better support regional socio-economic structural transformation, in addition to innovative actions on the firm level. The 'role of human agency in new path creation' (Simmie, 2013, p. 171) has also gained increasing attention recently. In this view, new pathways 'require social action by knowledgeable pioneering individuals, universities, companies and/or governments' (Simmie, 2012, p. 769), and mindful deviation from existing structures by entrepreneurs is seen to constitute the heart of path creation (Garud and Karnøe, 2001, p. 6). This approach emphasises the importance of strategic agency of knowledgeable entrepreneurs who mindfully deviate from established ways of doing things. These are entrepreneurs who are able to break with existing social rules, technological paradigms and trajectories.

Isaksen et al. (2019) distinguish between two main types of agency, amongst other things to be able to focus on actions aiming to transform RISs. Firm-level agency considers how actors start new innovative ventures or initiate new activities in existing firms or organisations. Entrepreneurs are traditionally understood as individuals who start new firms more or less on their own. 'Schumpeter's entrepreneur is always a single human being acting strategically' (Weik, 2011, p. 471); Alsos et al. (2014, p. 97) maintain that 'entrepreneurship research traditionally views both the individual and the firm as decontextualized entities'. The innovation system approach has since the 1990s contributed to a change in the understanding of entrepreneurship and innovation activity as driven by individual actors to also include social and economic structures surrounding entrepreneurship and innovation (Lundvall, 1992; Porter, 1998; Spigel and Harrison, 2018). Entrepreneurship is then considered as 'the result of the interaction between individual actors and the surrounding environment' (Bosma et al., 2011, p. 484).

In addition, several studies point to the fact that firm-level agency is most often not a sufficient condition to initiate regional structural change. 
In their study of the development of the wind turbine industry in Denmark and the US, Garud and Karnøe (2003), for example, use the concepts of distributed agency. This points towards how successful introduction of a new technology relies not only on those who introduce the technology in the market, but also on those who develop complementary assets and rivalling technology, on customers, on policy actors and so on. Thus, agency is distributed across multiple actors.

Distributed agency points to the second type of agency, i.e. system-level agency, which is linked to the RIS approach. System-level agency includes actions or interventions able to reconfigure RISs, and the 'industrial milieu' more generally, to better support growing industries and socioeconomic restructuring. The defining characteristic of system-level agency is that actors exert influences outside their institutional or organisational boundaries.

The distinction between firm-level and system-level agency and actors resembles the 'trinity of change agency' as put forward by Grillitsch and Sotarauta (2018). The first type of change agents includes innovative entrepreneurs. These are key actors for change as they are able to break 'with existing paths and work towards the establishments of new ones' (Grillitsch and Sotarauta, 2018, p.11). The second group of change agents in this typology is institutional entrepreneurs. These are individuals, organisations or groups of actors who 'mobilize resources, competence, and power to create new institutions or to transform existing institutions' (Sotarauta and Pulkkinen, 2011, p. 98). Institutions, in the meaning of 'taken-for-granted, culturally embedded understandings' (Garud et al., 2007, p. 958), change slowly and thus tend to support the continuation of existing activities and procedures, and therefore usually support existing paths. Institutional change is then important for 'moulding rules of the game and playing fields for innovative entrepreneurs to surface and succeed' (Grillitsch and Sotarauta, 2018, p.13). Institutional entrepreneurs may include policy makers, politicians, university leaders and firm leaders, who act intentionally and strategically. A common characteristic is a 'capacity to reflect and act in ways other than those prescribed by taken-for-granted rules' (Garud et al., 2007, p. 961). The third type of change agents are actors performing place leadership (Grillitsch and Sotarauta, 2018). Firms that represent seeds for new regional growth paths need access to sufficient resources and knowledge to be able to grow. 'This calls for a collective mobilisation of resources to support the emergence and growth of new paths' (Grillitsch and Sotarauta, 2018, p. 13), i.e. place leadership.

Similar arguments to those linked to system-level agency and institutional entrepreneurship are also put forward by Musiolik, Markard and Hekkert (2012). These authors regard system building as an important 
activity in the development of technological innovation systems that are able to support emerging business fields. 'System building is the deliberate creation and modification of broader institutional and organisational structures . . . carried out by innovating actors' (Musiolik et al., 2012, p. 1035). System building is regarded as a collective approach by a number of actors who join forces in networks. A key to changes in technological innovation systems is the interplay and deployment of resources at the organisational, network and system levels.

We have so far argued that regional structural change often requires deliberate initiatives to transform RISs by system-level actors at the same time as firm-level actors establish new firms or conduct innovations in existing firms that contribute to initiating a new path. The distinction between firm-level agency and system-level agency can provide the basis for two different, simple 'roads' to transformation (Isaksen et al., 2019).

A firm-oriented road starts when firm-level actors come up with new ideas, inventions or innovations that can contribute to upgrade existing or create new regional paths. However, two other conditions must be present for a new path to appear. Firstly, the innovation developed by the forerunners has to be employed and possibly adapted and improved by several other firm actors so that a critical mass of firms or organisations using a new technology, producing a new product or service, and so on, emerges (Foray, 2015). Secondly, the RIS needs to be transformed to better fit an emerging new or altered regional path. In this case, firm-level agency as it were 'pushes' forward changes in the RIS. The development starts at the firm level, but, as argued above, system-level agency plays an important role in reconfiguring wider RIS structures.

The other route, i.e. the RIS-oriented road, has its origin in system-level actors developing and adapting RISs to better fit real or assumed needs of possible new industries, technologies, business models and so on. Examples of system-level agency are the establishment of new organisations that contribute to the commercialisation of research ideas or to testing and experimenting with new green technologies, and the adaption of policy tools to support emerging industries or new social practices or to enable regulations to protect firms in new market niches. The idea is then that firm-level actors in new and existing firms respond to new possibilities introduced through RIS reconfiguration, which can lead to the fact that more firms and organisations use new knowledge and skills, and a new regional path can emerge though the diffusion and adaptation of new technologies and social practices.

A possible drawback with the second road is lack of relevant responses from firm-level actors and other organisations. This can lead to a classic 'cathedral in the desert' situation, which occurs when the regional actors 
lack absorptive capacity to utilise knowledge and technology found in the RIS. This points to the fact that system-level and firm-level agency need to be coordinated, i.e. that competence and other assets should be built on both the system and the organisational levels.

\section{CONCLUSIONS}

In this chapter, we have demonstrated that the RIS approach has played and continues to play - a powerful role in informing the design and implementation of regional innovation policies. RIS scholars have begun to complement their traditional focus on 'innovation for economic growth' by directing more attention to novel solutions that contribute to solving grand societal challenges such as climate change, resource depletion, the ageing of society, and increasing territorial and social inequalities. As shown in this chapter, the RIS approach continues to produce important insights on how to boost regional economic and societal development, not least due to recent advances of the concept that pay more attention to the direction and desirability of innovation and change, take account of new innovation actors not covered by the traditional triple-helix approach, and outline how to think about (and promote) RIS dynamics, i.e. the reconfiguration of regional organisational and institutional support structures in order to meet current and future economic and societal problems.

\section{NOTES}

1. In this context it is quite a paradox that the linear view still has quite a lot of influence in important agencies responsible for (regional) innovation policy. One example is the EU Commission's Directorate-General for Research (DG Research).

2. Porter has obviously read Perroux, as his cluster theory closely resembles Perroux's 'Growth Pole' approach. In the original presentation of his approach, in The Competitive Advantage of Nations (1990), clusters referred mainly to non-agglomerated, national industrial clusters (cf. Perroux's ideas about abstract economic space) (Porter, 1990, p.149), even if some of the case studies (e.g. industrial districts in the 'Third Italy') referred to agglomerated regional clusters. In his 1998 article in Harvard Business Review, he defines clusters as regional clusters only (Porter, 1998) (cf. Perroux's writing on concrete geographic space).

\section{REFERENCES}

Alsos, G.A., Carter, S., and Ljunggren, E. (2014). Kinship and business: How entrepreneurial households facilitate business growth. Entrepreneurship \& Regional Development, 26(1-2), 97-122. 
Asheim, B.T. (2012). The changing role of learning regions in the globalising knowledge economy: A theoretical re-examination. Regional Studies, 46(8), 993-1004.

Asheim, B.T., and Gertler, M.S. (2005). The geography of innovation: Regional innovation systems, in J. Fagerberg, D.C. Mowery and R. Nelson (eds), The Oxford Handbook of Innovation, Oxford, UK: Oxford University Press, pp. 291-317.

Asheim, B.T., and Isaksen, A. (1997). Location, agglomeration and innovation: Towards regional innovation systems in Norway? European Planning Studies, 5(3), 299-330.

Asheim, B.T., and Moodysson, J. (2017). Innovation policy for economic resilience: The case of Sweden. CIRCLE Papers in Innovation Studies 2017/5, Lund University, Sweden.

Asheim, B.T. et al. (2006). Constructing Regional Advantage: Principles-Perspectives - Policies. Final report from DG Research Expert Group on 'Constructing Regional Advantage'. DG Research, European Commission, Brussels.

Asheim, B.T., Boschma, R., and Cooke, P. (2011). Constructing regional advantage: Platform policies based on related variety and differentiated knowledge bases. Regional Studies, 45(7), 893-904.

Asheim, B.T., Grillitsch, M., and Trippl, M. (2016). Regional innovation systems: Past - present - future, in R. Shearmur, C. Carrincazeaux and D. Doloreux (eds), Handbook of the Geographies of Innovation, Cheltenham, UK and Northampton, MA, USA: Edward Elgar Publishing, pp. 45-62.

Asheim, B.T., Grillitsch, M., and Trippl, M. (2017). Smart Specialisation as an innovation-driven strategy for economic diversification, in S. Radosevic, A. Curaj, R. Gheorgiou, L. Andreescu and I. Wade (eds), Advances in the Theory and Practice of Smart Specialisation, Amsterdam: Elsevier Science Publishers, pp. 74-97.

Asheim, B., Isaksen, A., and Trippl, M. (2019). Regional Innovation Systems: An Advanced Introduction. Cheltenham, UK and Northampton, MA, USA: Edward Elgar Publishing.

Bellini, N., and Landabaso, M. (2007). Learning about innovation in Europe's regional policy, in R. Rutten and F. Boekema (eds), The Learning Region: Foundations, State of the Art, Future, Cheltenham, UK and Northampton, MA, USA: Edward Elgar Publishing, pp. 231-51.

Boschma, R. (2014). Constructing regional advantage and Smart Specialisation: Comparison of two European policy concepts. Italian Journal of Regional Science, 13(1), 51-65.

Boschma, R., Coenen, L., Frenken, K., and Truffer, B. (2017). Towards a theory of regional diversification: Combining insights from Evolutionary Economic Geography and Transition Studies. Regional Studies, 51(1), 31-45.

Bosma, N., Schutjens, V., and Stam, E. (2011). Regional entrepreneurship, in P. Cooke, B. Asheim, R. Boschma, R. Martin, D. Schwartz and F. Tödtling (eds), Handbook of Regional Innovation and Growth, Cheltenham, UK and Northampton, MA, USA: Edward Elgar Publishing, pp. 482-94.

Bush, V. (1945). Science: The Endless Frontier. Washington, DC: United States Government Printing Office.

Cooke, P. (1992). Regional innovation systems: Competitive regulation in the new Europe, Geoforum, 23(3), 365-82.

Emirbayer, M., and Mische, A. (1998). What is agency? The American Journal of Sociology, 103(4), 962-1032. 
European Commission (2014). National/regional innovation strategies for smart specialisation (RIAS3). Brussels: European Commission.

Foray, D. (2015). Smart Specialisation: Opportunities and Challenges for Regional Innovation Policy. London and New York, NY: Routledge.

Freeman, C. (2004). Technological infrastructure and international competitiveness, Industrial and Corporate Change, 13(3), 541-69.

Garud, R., and Karnøe, P. (2001). Path creation as a process of mindful deviation, in R. Garud and P. Karnøe (eds), Path Dependence and Creation, Hillsdale, NJ: Lawrence Erlbaum Associates, pp. 1-38.

Garud, R., and Karnøe, P. (2003). Bricolage versus breakthrough: Distributed and embedded agency in technology entrepreneurship. Research Policy, 32(2), 277-300.

Garud, R., Hardy, C., and Maguire, S. (2007). Institutional entrepreneurship as embedded agency: An introduction to the special issue. Organization Studies, 28(7), 957-69.

Grabher, G. (1993). The weakness of strong ties: The lock-in of regional development in the Ruhr area, in G. Grabher (ed.), The Embedded Firm: On the Socioeconomics of Industrial Networks. London and New York, NY: Routledge, pp. $255-77$.

Grillitsch, M., and Sotarauta, M. (2018). Regional Growth Paths: From Structure to Agency and Back. CIRCLE, University of Lund, Lund: Papers in Innovation Studies. Paper no. 2018/01.

Hirschman, A.O. (1958). The Strategy of Economic Development. New Haven, CT: Yale University Press.

Holland, S. (1976). Capital versus the Regions. Basingstoke: Macmillan.

Isaksen, A., and Trippl, M. (2016). Path development in different regional innovation systems: A conceptual analysis, in M.D. Parrilli, R.D. Fitjar and A. RodríguezPose (eds), Innovation Drivers and Regional Innovation Strategies, London: Routledge, pp. 66-84.

Isaksen, A., Jakobsen, S.E., Njøs, R., and Normann, R. (2019). Regional industrial restructuring resulting from individual and system agency. Innovation: The European Journal of Social Science Research, 32(1), 48-65.

Lundvall, B.A. (ed.) (1992). National Systems of Innovation: Towards a Theory of Innovation and Interactive Learning. London: Anthem Press.

Lundvall, B.A., and Borrás, S. (2005). Science, technology, and innovation policy, in J. Fagerberg, D.C. Mowery and R. Nelson (eds), The Oxford Handbook of Innovation, Oxford, UK: Oxford University Press, pp. 599-631.

Mazzucato, M. (2017). Mission-Oriented Innovation Policy: Challenges and Opportunities, Institute of Innovation and Public Purpose (IIPP) Working Paper, 2017-1.

Miörner, J., and Trippl, M. (2017). Paving the way for new regional industrial paths: Actors and modes of change in Scania's games industry. European Planning Studies, 25(3), 481-97.

Musiolik, J., Markard, J., and Hekkert, M. (2012). Networks and network resources in technological innovation systems: Towards a conceptual framework for system building. Technological Forecasting \& Social Change, 79, 1032-48.

Myrdal, G. (1957). Economic Theory and Underdeveloped Regions. London: Gerald Duckworth.

OECD (2015). System Innovation: Synthesis Report. Paris: OECD.

Oliveira, P., Zejnilovic, L., Canhão, H., and von Hippel, E. (2015). Innovation by 
patients with rare diseases and chronic needs. Orphanet Journal of Rare Diseases, 10(41), 2-9.

Perroux, F. (1970). Note on the concept of Growth Poles, in D. McKee, R. Dean and W. Leahy (eds), Regional Economics: Theory and Practice, New York, NY: The Free Press, pp. 93-103.

Piore, M.J., and Sabel, C (1984). The Second Industrial Divide: Possibilities for Prosperity. New York, NY: Basic Books.

Porter, M.E. (1990). The Competitive Advantage of Nations. London: Macmillan.

Porter, M.E. (1998). Clusters and the new economics of competition. Harvard Business Review, 77-90.

Schot, J., and Steinmueller, E. (2018). Three frames for innovation policy: R\&D, systems of innovation and transformative change. Research Policy, 47(9), 1554-67.

Simmie, J. (2012). Path dependence and new technological path creation in the Danish wind power industry. European Planning Studies, 20(5), 753-72.

Simmie, J. (2013). Path dependence and new technological path creation in the economic landscape, in P. Cooke (ed.), Re-framing Regional Development: Evolution, Innovation and Transition, London and New York, NY: Routledge, pp. 164-85.

Sotarauta, M., and Pulkkinen, R. (2011). Institutional entrepreneurship for knowledge regions: In search of a fresh set of questions for regional innovation studies. Environment and Planning C: Government and Policy, 29, 96-112.

Sotarauta, M., and Suvinen, N. (2018). Institutional agency and path creation: Institutional path from industrial to knowledge city, in A. Isaksen, R. Martin and M. Trippl (eds), New Avenues for Regional Innovation Systems: Theoretical Advances, Empirical Cases and Policy Lessons, Berlin: Springer, pp. 85-104.

Spigel, B., and Harrison, R. (2018). Towards a process theory of entrepreneurial ecosystems. Strategic Entrepreneurship Journal, 12(1), 151-68.

Tödtling, F., and Trippl, M. (2005). One size fits all? Towards a differentiated regional innovation policy approach. Research Policy, 34(8), 1203-19.

Tödtling, F., and Trippl, M. (2013). Transformation of regional innovation systems: From old legacies to new development paths, in P. Cooke (ed.), Reframing Regional Development: Evolution, Innovation and Transition. London and New York, NY: Routledge, pp. 297-317.

Tödtling, F., and Trippl, M. (2018). Regional innovation policies for new path development: Beyond neoliberal and traditional systemic views. European Planning Studies, 26(9), 1779-95.

Trippl, M., Grillitsch, M., and Isaksen, A. (2018). Exogenous sources of regional industrial change: Attraction and absorption of non-local knowledge for new path development. Progress in Human Geography, 42(5), 687-705.

Trippl, M., Zukauskaite, E., and Healy, A. (2019). Shaping Smart Specialisation: The role of place-specific factors in advanced, intermediary and less-developed European regions. RegionalStudies(in press), doi: 10.1080/00343404.2019.1582763

Weber, K.M., and Truffer, B. (2017). Moving innovation systems research to the next level: Towards an integrative agenda. Oxford Review of Economic Policy, 33(1), 101-21.

Weik, E. (2011). Institutional entrepreneurship and agency. Journal of the Theory of Social Behaviour, 44(4), 466-81.

Zukauskaite, E., Trippl, M., and Plechero, M. (2017). Institutional thickness revisited. Economic Geography, 93(4), 325-45. 